\title{
LEARNING IN LATER LIFE: THE PERSPECTIVE OF SUCCESSFUL AGEING
}

\section{ŠATIENĖ Salomėja}

Klaipèda State University of Applied Sciences, Klaipėda, Lithuania

\begin{abstract}
The integrated approach to the development of educational theory of later life learning should be informed by comprehensive knowledge of ageing as a social construct. Establishment of the role of later life learning in the context of successful ageing paradigm encompasses both sociological and educational perspectives taking into consideration the complexity of older people's engagement in society and participation in education with regard to social use for the learning outcomes and personal growth. In the context of successful ageing, it should provide the answers to the questions related to the meaning and role of learning in later life. The present research aims to explore the role of learning in the construct of successful ageing and to analyze the characteristic features of non-formal later life learning in Lithuania in the perspective of successful ageing based on the review some recent literature on psychological and social aspects of successful ageing and older adult education and research in the fields of educational and psychosocial gerontology. It pursues answers to the questions as to "How can learning in later life contribute to successful ageing? What are the implications for the role of learning in the models of successful ageing? How is the role of third-age learning conceptualized in the perspective of successful ageing?" The answers to these questions provide better insight into the conceptual background of older adult education and suggests prospective research on the issue of the role of learning in older age. The multidimensional nature of the concept of successful ageing revealed by the literature review suggests that the role of learning in the construct of successful ageing is analyzable in relationship with health, psychological and social domains. The role of learning in later life is manifested through its impact on maintenance of cognitive function, psychological resources and social functioning. The positive impact of learning in later life on mental health through maintenance of cognitive function and the utilization of psychological resources through stimulation of personal growth and self-efficacy of older adult learners has been supported by findings of many recent studies. Education has been identified as one of the predictors of active engagement with life as an essential component of successful ageing.
\end{abstract}

Keywords: Ageing; Conceptualisation; Education; Later life learning.

\section{Background}

Ageing of population places an increased emphasis on education to be continued in later life. Development of the theory of older adult education requires awareness of the national and global processes and acknowledgement of the demands of the aging society on education, determined by the sociocultural context. The integrated approach to the development of educational theory of later life learning should be informed 
by comprehensive integrated knowledge of aging as a social construct. In the recent years, there have been some studies on psychological and social aspects of the issue of successful ageing published in Lithuania (Čepènaitė, 2008; Jankunaite \& Naujaniene, 2012; Miežytė-Tijūšienė \& Bulotaitė, 2012; Mockus \& Žukaitè, 2012). However, the issue of older adult education has not been analyzed in the perspective of ageing yet. There has not been carried out any in-depth research of learning in old age based on conceptual frameworks of the role and meaning of learning in older age. Furthermore, in the development of educational gerontology theory in Lithuania, there is lack of scientific discussion on the issues of older people learning in general and in the perspective of successful ageing in particular. The multidimensionality of the concept of successful ageing requires some integrative approach which allows analysis of later life education to be grounded in both psychosocial theories of ageing and the change of educational paradigms in the context of lifelong learning. In the context of successful ageing, it should provide the answers to the questions related to the concept of later life education, the meaning and role of learning in later life, and the image of the individual educated. The research focus of the present study is integration of the aspect of later-life learning in the models of successful ageing. The aim of the present study is to provide theoretical analysis of the role of older adult learning in the context of successful ageing based on the contemporary psychosocial and educational theories and research.

In the present study we will explore the role of learning in the construct of successful ageing and will analyze the characteristic features of non-formal third-age learning in Lithuania in the perspective of successful ageing. The following questions are raised in this research: How can learning in later life contribute to successful ageing? What are the implications for the role of learning in the models of successful ageing? How is the role of third-age learning conceptualized in the perspective of successful ageing? The answers to these questions will provide better insight into the conceptual background of older adult education and will suggest prospective research on the issue of the role of learning in older age. Establishment of the role of late-life learning in the context of successful ageing paradigm encompasses both sociological and educational perspectives taking into consideration the complexity of older people's engagement in society and participation in education with regard to social use for the learning outcomes and personal cognitive growth. Therefore the issue will be addressed from the social constructionism perspective.

\section{Methodology}

The method used in the study was the literature review by including the primary sources and presenting data from quantitative and qualitative studies, and some secondary sources presenting reviews related to the topic. The scientific literature review allowed to provide the basic for a new approach to the research issue and to plan its further development of the research methodology (Kardelis, 2002) for the further empirical 
research. In this paper is reviewed the literature on psychological and social aspects of ageing and older adult education, and research in the fields of educational and psychosocial gerontology.

\section{Findings}

\section{The role of learning in successful ageing}

Educational theory of learning in later life can only be conceptualized as interrelated with social and developmental theories of ageing, which provide background for identification of the role of learning in the later stages of the life continuum. In the recent decades, "successful aging" has become a key concept and construct in gerontological research. As a multidimensional concept by its nature, it has been analyzed in a considerable number of studies proposing different models from perspective of various disciplines (Rowe $\&$ Kahn, 1997; Strawbridge et al., 2002; Phelan, Anderson et al., 2004; Boulton-Lewis, 2010). Biomedical approaches focus on health issues in old age, emphasizing absence of disease or disability and maintenance of physical and mental functioning as key factors to successful ageing, whereas sociopsychological models emphasize life satisfaction, social participation and functioning, and psychological resources (Bowling \& Dieppe, 2005). Bowling and Dieppe (2005) ponted that the most concepts of successful ageing are used uncritically and tend to reflect the academic discipline of the investigator, and attempts to build interdisciplinary models are still rare.

Rowe and Kahn's multidimensional model (1998) is one the most widely used in gerontological research and scientific discussion. Within the conceptual framework of this model, successful ageing is defined as a successful adaptive and preventive strategy comprising three main components: low probability of disease or disability, high cognitive and physical functional capacity and active engagement with life. Strawbridge et al. (2002), having compared the results of their research to those of Rowe and Kahn (1997), suggested that the aforementioned criteria might not be sufficient, as successful ageing appears to be a more complex concept. Phelan et al. (2004) identified twenty attributes as related to the physical, functional, psychological, and social health components of successful ageing. In two Australian studies, analyzed by Boulton-Lewis (2010), the concept of active ageing was defined as being proactive in keeping healthy, being physically and mentally active, engaging in learning, living in safe environments, working, and actively participating in family and community life. Bowling and Dieppe (2005), having undertaken a systematic literature review of successful ageing, identified three most examined domains used in scientific research to define successful aging: physical and mental functioning, psychological well-being, and social functioning. Taking into consideration the multidimensional nature of the concept of successful ageing,the role of learning in the construct of successful ageing is analyzable in relationship with health, psychological and social components, i.e. investigating the impact of learning on maintenance of cognitive function, psychological resources and social functioning. 


\section{Impact of learning on mental health through maintenance of cognitive function}

Age-related cognitive decline is of key concern to contemporary aging research which creates the need for establishing the key dimensions for enhancing the cognitive abilities of elderly adults. Education and learning in older age has been identified as a major protective factor against reductions in cognitive function in a considerable number of studies, showing that cognitive function can be both maintained and enhanced in old age (Rowe \& Kahn, 1997; Phelan et al., 2004; Boulton-Lewis et al., 2006; Tam, 2013), and brain aging may be reversed through learning experiences (Merzenich, 2005; Mahncke et al. 2006; Green \& Bavelier 2008; Park \& Reuter-Lorenz, 2009). Merzenich (2005) has developed a theory that the neuronal structure can be changed by specifically designed mental exercises and has identified a number of strategies to overcome the age-related cognitive decline problems. Mahncke et al. (2006) point out that substantial improvement in function and/or recovery from losses should be possible using appropriately designed behavioral training paradigms and brain-plasticity-based training program would potentially be applicable to all aging adults with the promise of improving their operational capabilities. Green and Bavelier (2008) have also suggested development of new cognitive interventions that can be effectively applied to compensate for age-related cognitive decline. Park and Reuter-Lorenz (2009) have proposed the scaffolding theory of aging and cognition based on neuroplasticity. As pointed out by Guglielman (2012), the application of neuroscience theories about brain plasticity to adult education is essential to promote lifelong learning through the creation of learning environments. The researches on older learners' perception of the role of education in successful ageing showed that education and continued learning were rated highly by senior learners and were associated with mental health and improvement of intellectual abilities (Boulton-Lewis et al., 2006; Tam, 2013).

\section{Psychological resources and psychological well-being}

The positive impact of learning in later life on the psychological well-being of older adult learners has been supported by findings of many recent studies (Fok, 2010; Jamieson, 2012; Formosa, 2012; Hayslip \& Cooper, 2012; Tam, 2013). Formosa (2012) has examined the extent to which education or learning is perceived as important in the ageing process and stated that there has been a number of research on the benefits of late-life education through universities of the third age finding health and psychological benefits. Fok's study of learning experiences (2010) found that learning among older adults has important meaning in the aging process: the participants learn to embrace some of the changes and losses encountered in the later stages of their lives. Jamieson (2012) explored educational activity within the framework of a transitions model and showed the benefits of education in later life within the process of coping with life transitions and understanding the impact of time on individuals. Her study of the particular characteristics and experiences of a cohort of mature students in formal education programmes at a faculty of continuing education in a London University college showed how different individuals use formal educational activity in their coping strategy. Hayslip and Cooper's research into subjective and objective intellectual change in older adults 
(2012) showed that having a sense of control may help one minimize the negative consequences of declines and losses associated with aging. Educational and self-improvement activities and behaviors affect the confidence in one's ability to maintain one's skills in the face of ill health, loss, negative age stereotypes, or age discrimination in one's continued educational pursuits. Hayslip and Cooper (2012) claim that exposure to purposefully-designed training interventions as well as challenging oneself cognitively via everyday activities that promote the use of their skills and enrollment in continuing educational and lifelong learning activities that are complex, challenging, and novel as stimuli help promote and enhance one's potential of living an engaged lifestyle. Tam (2013) has pointed out a variety of reasons for older adults learning including spiritual or personal growth, enjoyment in learning something new, keeping up-to-date with what is happening in society and in the world, studying some subjects of interest or seeking help to adjust to the process of getting old.

\section{Social participation and functioning}

It has been generally recognized that the profile of older people has changed in the last decades - the contemporary generation of old people are well-educated and active, in contrast to stereotypes associating old age with ill-health, passivity and dependancy. This has been reflected in gerontological theory by emergence of a new approach associated with generativity in older age as a perspective to view contemporary generation of older learners. In this perspective, the aim of later life education is to develop competences enabling older people to contribute to their social contexts. Continued social functioning encompasses high levels of ability in social role functioning, positive interactions or relationships with others, social integration, and reciprocal participation in society (Bowling \& Dieppe, 2005). The reasearch into older adult learners ' perceptions of their participation in later life learning programmes identifies a need to make good use of their remaining years as well as keep up with the pace of society and be part of it (Fok, 2010). The importance of productivity in older age was also emphasized by Rowe and Kahn (1997) suggesting that productive activity is one of the most important forms of active engagement with life as an essential component of successful ageing and education is one of the predictors of productive activity. Active and productive functioning requires certain competences, which are based on acquisition of new knowledge and development of skills relevant to engagement in the new type of activity. Villar and Celdran (2012) maintain, that ,generativity model offers a more balanced picture of social and personal growth through participating in learning activities motivated by future-oriented and long-term values linked to the development and improvement of the social context in which they live.

Bowling and Dieppe (2005), having undertaken systematic literature review of successful ageing, sum up that successful ageing is seen as a dynamic process, as the outcome of one's development over the life course, and as the ability to grow and learn by using past experiences to cope with present circumstances while maintaining a realistic sense of self. Research indicates that many domains of successful ageing are 
inter-related, and learning activity is identified among the factors predicting successful ageing. The implications for the role of later life learning are associated with maintenance of mental functioning, development and utilization of psychological resources and continued social functioning.

\section{Non-formal third-age learning in Lithuania in the perspective of successful ageing}

In the recent years, in Lithuania, there has been considerable attention given to conceptualization of the role of older adult education at the national level in legal acts and national strategic documents regulating the development of adult education. The Law on Non-formal Adult Education and Continuing Learning (1998, 2014) has been amended, including an article on the university of the third age, the main function of which is defined in terms of provision of non-formal and continuous education for older adults meeting their needs for knowledge, competence development and cultural needs. However, there is no attention given to older adult education in the National Education 2013-2022 Strategy (2013), and the strategy itself may be considered ageist as in terms of lifelong learning it defines the adult age group as people aged 25 to 64 thus ignoring educational needs of those aged 64 and more. The Action Plan for Development of Non-formal Adult Education 2014-2016 (2014) acknowledges the need for creation of lifelong learning opportunities and stimulation of learning activities of older adults. This document emphasizes that educational needs of older adults should be met by providing conditions for dignity in old age and opportunities to return to the labour market. There is an aim set to create a system of lifelong learning, which will provide conditions for social and occupational inclusion of adult learners, their active citizenship and personality development. It sets an objective to provide conditions for adults to acquire generic competences and develop their positive attitudes towards lifelong learning.

The most recent strategic document related to ageing is the National Science Programme of „Healthy Ageing" (2015). The aim of the programme is complex analysis of and tackling biomedical and social medicine issues of healthy ageing of society by means of development of science and technology and application of the outcomes of fundamental and applied research. The programme seeks to create and develop measures and technologies for improving the opportunities for and aspirations of older people pursuing good health, security, active involvement in society and independence to very old age. The policy implications of this programme demonstrate that the biomedical approach to the concept of successful ageing has been adopted at the national level, which focuses on promotion of physical and mental health for achieving successful ageing. Although medical issues of ageing and healthy living are the main focus of this programme, it also emphasizes the comprehensive nature of health facilitating technologies integrating education, community involvement and community empowerment. 
Analysis of the legislative basis providing conceptual background to understanding the role of older adult education suggests that learning in older age is viewed from the generativity perspective, emphasizing older adults productivity, acquisition of knowledge and skills needed for continued social and occupational activity. ,Generativity“ model sees the aim of later life education to develop competencies that enable older people to contribute to the social contexts in which they participate (Villar \& Celdran, 2012).

In the educational science in Lithuania, there has been little attention given to the field of educational gerontology yet, which determines considerable uncertainty in the conceptualization of the role of nonformal older adult education both in terms of educational practice and research. The lack of scientific research in educational gerontology may be partially due to the fact pointed out by Butvylienè (2013), that it is difficult for non-formal adult education to establish itself as a specific sector in the education area, as the legal basis for regulation of assessment of the outcomes of and teacher training for non-formal adult education is still incomplete. Most of the research on successful ageing has been focused on psychological and social aspects. Although there have not been any studies with explicit application of interdisciplinary approach, which would integrate educational perspective into research on ageing, we can find some implications for later life learning in the psychosocial research carried out in the recent decade. Čepenaite (2008) in her study of the implementation of social measures for active participation of elderly people in community life emphasized cooperation with adult education institutions contributing to inclusion of elderly people and development of active citizenship.

Jankūnaite and Naujanienè (2012) in their study of the factors of successful ageing aimed to reveal the construction of the premises of successful ageing from the older people's perspective in Lithuania and found out that the main components of the successful ageing construct encompass relationships with other people, economic status, maintenance of health and rewarding activities. Mockus and Žukaitè (2012) in their study of psychological aspects of successful ageing emphasized cognitive activity, the reduction of which is associated with inadequate adaptation to new living circumstances - more extensive knowledge allows elderly people to select meaningful information in the environment and therefore older person's ability to learn and retain skills and meaningful material deteriorates less, whereas the creative abilities may even become more active in old age. The authors of the study established a close connection between cognitive activity and the psychological dimension stating that people with better cognitive abilities have a more positive view of their life in old age. Miežytė-Tijūšienè and Bulotaite (2012) revealed the positive impact of social activity on the psychological well-being in older age suggesting that stimulation of older people's social activity through involvement into interesting and stimulating activities facilitates successful ageing. However, the level of social activity among older people is not high. The level of education is a predictor of engagement in intellectual activity. The implications of the aforementioned research on psychosocial issues for later life education and learning might be seen in the fact that learning is believed to both help older people to become more knowledgable, skilled and motivated for productive activity and social participation, and promote better mental health and better utilization of psychological resources. 
In terms of field research, there have been three large-scale nationwide surveys of the state of older adult education carried out including The Report on the Applied Research of Adult Education (2011), The Analysis of the Activities of the Third Age University System (2012) and The Universities of the Third Age in Lithuania: Analysis of the situation and Development Guidelines (2014). The Report on the Applied Research of Adult Education (2011) was the first large scale study of older adult education in Lithuania. The study aimed at analyzing characteristics of adult education and learning focused on older adult learners (aged 55-74) as a socially disadvantaged group. The research covered the issues of the scale of older adult learning, motivation and learning experience, organizational aspects of education and legal regulation. The first large-scale study of the third-age learning in Lithuania, The Analysis of the Activities of the Third Age University System (2012), provided a comprehensive view of non-formal older adult education in Lithuania, its current state and problems. This was the first comprehensive research on the activities of the universities of the third age (UTAs) in Lithuania, which aimed at understanding and evaluation of UTAs as a social phenomenon, as a type of educational institution and a form of older adult learning. The aim of The Universities of the Third Age in Lithuania: analysis of the situation and development guidelines (2014), which in some respects was complementary to Analysis of the activity of the system of the third Age Universities (2012), was to establish the trends in the development of Universities of the third Age and prepare guidelines for futher development in terms of organizational, financial and strategic planning aspects.

Analysis of the results of the aforementioned surveys provides some basis for conceptualization of the role attributed to older adult education and learning in the context of successful ageing. The findings of the research show that non-formal older adult learning in Lithuania lacks conceptual grounding and therefore the universities of the third age are seen as a form of not only and not as much of academic activity but rather as leisure and socialization activity for older adults. As pointed out by Miežytė-Tijūšienè and Bulotaitè (2012), in their pursuit of an active lifestyle, retired people engage in the activity of their interest, and leisure becomes an important aspect of their subjective well-being. UTAs offer a large scale of areas of study and activities including healthy living, culture, history, social psychology, arts, foreign languages etc. which aims to meet the educational, cultural and leisure needs of participants with a broad range of educational and social backgrounds.

Older people's views of the role of learning are important for conceptualization of the role of third-age teaching and learning. The research of the perceptions of education in later life among people in middle and older age groups in Lithuania identified the main motivational factors of older adults learning, which include personal development, acquisition of knowledge, self-fulfillment and opportunities for communication with new people as well as economic factors - improvement of one's economic status through advancement and acquisition of new skills needed in the labour market (The Report on the Applied Research of Adult Education, 2011). The most popular reasons for learning at older age are self-development, broadening one's outlook and self-expression, and communication, and meeting new people, which shows that the main 
motivation for learning at older age is the inner drive of a person to be active and socialize with other people. Only some learners come for knowledge of a specific area or because they believe they must keep up with those participating in education. In the range of expectations and benefits of learning identified by the learners, acquisition of new useful knowledge and socializing with new people are named as the top priorities. Application of the newly acquired knowledge in everyday life and development of one's knowledge and skills were also considered important (Analysis of the activity of the system of the third Age Universities, 2012). The variety of subjects for potential learning show the multidimensional nature of the learning needs of older adults and the role they attribute to learning in later life. Although some UTAs are oriented towards academic activity in the form of lectures for older people, some develop both academic and cultural activity with orientation to active leisure. In general they organize different kinds of activities which might be of any interest to older people with no clear bias in academic activity (The Universities of the Third Age in Lithuania: analysis of the situation and development guidelines, 2014). There is also a necessity to develop and apply adequate theoretical grounding to the practice of older adult education. The authors of the research in their discussion of the findings and formulation of the conclusions and recommendations for older adult education adopted the social activity perspective of older adults engagement in learning, associating the main function of older adult participation in education and training with meeting the social needs of aging population and prevention of social marginalization, providing opportunities for them to remain active citizens contributing to society rather than engaging in learning activities due to academic or cognitive reasons. The former type of reasons was also identified by senior people themselves. The priority is given to activities related to occupational training and development of flexible forms of activity. The authors suggest that the educational system should provide the senior people with knowledge and skills needed to organize voluntary activities, establishment of interest clubs and creating opportunities for nonformal education and artistic activities. However, older adults need certain knowledge and skills as well as self-efficacy to engage in such activities. The findings of the research suggest that education and consultancy services for older people should be orientated towards formation of skills for taking part in community activities, effective skills of information search, encouragement of self-efficacy and meeting the needs for communication and personal development. These results are consistent with findings of other studies of elder people learning, which showed that older learners prefer to learn for life-enrichment and self-fulfillment and the variety of reasons for older adults learning encompass personal growth, enjoyment in learning something new, keeping up-to-date with what is happening in society and in the world, studying some subjects of interest or seeking help to adjust to the process of getting old (Tam, 2013).

The results of the studies showed low participation levels in older adult education and training. This may be illustrated by the fact that 3 out of 4 ( 79 per cent) of older adults are not involved in any kind of education or training (The Report on the Applied Research of Adult Education, 2011). The findings of this research are consistent with the low participation trend identified by some earlier research (Report on the Development of opportunities for adult continuous education in the context of implementation of the Lifelong learning 
strategy, 2004). The statistical data provided by the survey on UTAs in Lithuania also demonstrate low enrollment levels. In 2011-2012, there were only about 5400 people involved in the University of the Third Age (UTA) education out of the population of 711,036 aged over 60. In 2013-2014 there were 8400 older people engaged in this type of education out of 659.7 thousand population of retirement age respectively (The Universities of the Third Age in Lithuania: analysis of the situation and development guidelines, 2014). Although there is a trend of rapid increase in the number of older people participating in the third-age education, the general low participation rate indicates that majority of older adults do not take advantage of third-age education opportunities.

The surveys have indicated not only low participation levels, but also showed that involvement in learning decreases with increasing age. Similar findings were reported in a considerable number of studies conducted in different countries (Tam, 2013; Guglieman, 2010, Findsen \& Formosa, 2011, etc.), manifesting a prevailing downward trend in older adult participation. The major difficulty that elderly people have in learning is the deterioration of mental abilities due to age-related decline (Mahncke et.al, 2006) and lack of motivation (Formosa, 2012). The surveys in Lithuania showed that 2 out of 3 people aged 55 to 74 do not have a need for learning. Furthermore, older people have negative attitudes to learning in older age: 2 out of 3 older adults (61 per cent) were convinced that it was too late for them to learn at their age (The report on the applied research of adult education, 2011). These findings are consistent with those of some previous research in Lithuania, suggesting that most old people doubt their ability to learn (Mickūnaite, 2008). The level of previous education is also a predictor of engagement in intellectual activity (Miežytè-Tijūšienè \& Bulotaite , 2012). Some explanation to the reasons for the negative attitudes towards education in later years can be found in research carried out in other countries and scientific discussion in the field of educational gerontology. Negative age stereotypes, or age discrimination, and lack of self-efficacy may have a negative effect on older adults learning motivation. However, stimulation of utilization of one's psychological resources through educational and self-improvement activities and behaviors may affect the confidence in one's ability to maintain one‘s skills in one's continued educational pursuits (Hayslip \& Cooper, 2012).

The profile of the older adults with the lowest motivation for learning identifies lower levels of education, unemployment status, lower income and rural residence (The Report on the Applied Research of Adult Education, 2011). Even though some older adults believe that it is never too late to learn, they see no meaning in learning at later age, as this is unlikely to change their employment situation. Some older people even consider it inappropriate to be encouraged to learn at their age. They view the need for professional development, learning or even acquisition of a new qualification as alien to them and oppose it. Most of these people are not ready for change, they do not possess the skills needed for learning and they are not ready to change their habits, beliefs or abilities. Mickūnaite (2008) investigated the concept of vulnerable group adult learning in the lifelong learning culture from the perspective of older adults associated with socially vulnerable groups in Lithuania, and came to the conclusion that although these adults acknowledge the value of learning, they associate the learning opportunities with the people at a more advantaged 
situation. Therefore development of lifelong learning culture and integration of the adults of vulnerable groups requires rethinking of the image of education as simple, available and accessible to people from all strata of society (Mickūnaitè, 2008). As pointed out by Bowling and Dieppe (2005), interventions need to target potentially vulnerable groups early on, as several longitudinal studies have shown that variables measured in middle age predict outcomes in old age and adaptation to old age is related to experiences of stressful events, and associated with social class. Further research is needed into the reasons for the negative attitudes towards education in later years as well as into the educational needs of contemporary generation of older adults, based on older adults' perceptions of the role they attribute to learning in later life, which may provide better insight into conceptualization of the role of learning in successful ageing.

\section{Conclusion}

The multidimensional nature of the concept of successful ageing revealed by the literature review suggests that the role of learning in the construct of successful ageing is analyzable in relationship with health, psychological and social domains. The role of learning in later life is manifested through its impact on maintenance of cognitive function, psychological resources and social functioning. The positive impact of learning in later life on mental health through maintenance of cognitive function and the utilization of psychological resources through stimulation of personal growth and self-efficacy of older adult learners has been supported by findings of many recent studies. Education has been identified as one of the predictors of active engagement with life as an essential component of successful ageing.

Analysis of the legislative basis of non-formal adult education in Lithuania provides conceptual background to understanding the role of older adult education and suggests that learning in older age is viewed from the generativity perspective, emphasizing older adults productivity, acquisition of knowledge and skills needed for continued social and occupational activity. In the educational science in Lithuania, there has been little attention given to the field of educational gerontology yet, which determines considerable uncertainty in the conceptualization of the role of non-formal older adult education both in terms of educational practice and research. Most of the research on successful ageing carried out in Lithuania in the recent decade has been focused on psychological and social aspects with some implications for later life learning as suggesting that learning is believed to both help older people to become more knowledgable, skilled and motivated for productive activity and social participation, and promote better mental health and better utilization of psychological resources. Analysis of the results of the recent nationwide surveys based on the perceptions of older adults of the role of education in later life provides some basis for conceptualization of the role attributed to older adult education and learning in the context of successful ageing. The main motivational factors of older adults learning, which include personal development and selffulfillment, acquisition of knowledge, and improvement of one's economic status through advancement and acquisition of new skills needed in the labour market, manifest the generativity perspective in the attitude of 
the contemporary older generation to learning in later life. The variety of subjects for potential learning show the multidimensional nature of the learning needs of older adults and respectively the role they attribute to learning in later life. The low rate of participation in the third-age education and the decreasing involvement in learning with increasing age indicate that majority of older adults do not take advantage of third-age education opportunities, especially in later life. Further research is needed into the reasons for the negative attitudes towards education in later years as well as into the educational needs of contemporary generation of older adults in Lithuania, based on older adults' perceptions of the role they attribute to learning in later life, which may provide better insight into conceptualization of the role of learning in successful ageing.

\section{References}

Boulton-Lewis, G.M. (2010). Education and Learning for the Elderly: Why, How, What. Educational Gerontology, 36(3), 213-228.

Boulton-Lewis, G. M., Buys, L., \& Lovie-Kitchin, J. (2006). Learning and active aging. Educational Gerontology, 32(4), 271-282.

Bowling, A., \& Dieppe, P. (2005). What is successful ageing and who should define it. British Medical Journal, 331, $1548-1551$.

Butyvilienè, J. (2013). Neformalusis suaugusiujų švietimas: valstybinis ir privatus mokymo sektoriai. Acta Paedagogica Vilnensia, 30, 126-136.

Čepėnaitè, A. D. (2008). Senyvo amžiaus žmonių socialinė aprèptis ir demokratinio pilietiškumo apraiškos. Socialinis darbas, 7(1), 46-56.

Fok, S.-Y. (2010). The Meaning of the Learning Experiences of Older Adults in Hong Kong. Educational Gerontology, 36(4), 298-311

Formosa, M. (2012). Education and Older Adults at the University of the Third Age, Educational Gerontology, 38(2), 114-126.

Green, C. S., \& Bavelier, D. (2008). Exercising your brain: A review of human brain plasticity and training-induced learning. Psychology and Aging, 23, 692-701.

Guglielman, E. (2012). The aging brain: Neuroplasticity and lifelong learning. eLearning Papers. No. 29. Available at <www.elearningpapers.eu> (Retrieved on 03/05/2015).

Hayslip, B. Jr. \& Cooper, A.M. (2012). Subjective and Objective Intellectual Change in Older Adults. Educational Gerontology, 38, 190-200.

Jankūnaitè, D., \& Naujanienè, R. (2012). Sèkmingos senatvès prielaidos: senyvo amžiaus asmenų perspektyva. Social work. Experience and methods, 10(2), 209-232.

Kalvaitis, A., Barauskienė, J., Jankūnaitè, D., \& Naujanienè, R. (2012). Sėkmingos senatvės prielaidos Mačènaitè, A. (2014). Trečiojo amžiaus universitetai Lietuvoje: situacijos analizè ir plètros gairès. Vilnius: Ugdymo plètotès centras.

Kardelis, K.. (2002) Moksliniu tyrimu metodologija ir metodai. Šiauliai: ŠU leidykla.

Lietuvos Respublikos Neformaliojo suaugusiuju švietimo ịstatymas (1998, 2014). Žin., 1998, Nr.66-1909; TAR, 201407-22, Nr. 10429. 
Mahncke, H.W., Bronstone, A., \& Merzenich, M. M. (2006). Brain Plasticity and Functional Losses et al. (2006). Brain Plasticity and Functional Losses in the Aged: Scientific Bases for a Novel Intervention. Progress in Brain Research, 157, 81-109.

Merzenich, M.M. (2005). Change minds for the better. The Journal on Active Aging. November/December: $22-29$. Available at https://sites.oxy.edu/clint/physio/article/Changemindsforthebetteragingcognition.pdf (Retrieved from 04/02/2015).

Mickūnaitè, E. (2008). Rizikos grupių suaugusiųjų požiūris ị mokymąsi. Acta Paedagogica Vilnensia, 21, $149-159$.

Miežytè-Tijūšienè, J., \& Bulotaitè, L. (2012). Pensinio amžiaus žmonių socialinis aktyvumas bei psichologinė savijauta. Gerontologija, 13(4), 199-205.

Mockus, A., \& Žukaitè, A. (2012). Sèkmingas senėjimas: psichologinis aspektas. Gerontologija, 13(4), $228-234$.

Neformaliojo suaugusiujų švietimo pletros 2014-2016 metu veiksmu planas (2014). Lietuvos Respublikos švietimo ir mokslo ministro 2014 m. spalio 9 d. įsakymas Nr. V-893. TAR, 2014-10-13, Nr. 14016.

Nacionalinè mokslo programa „,Sveikas senejjimas“ (2015). Lietuvos Respublikos švietimo ir mokslo ministro 2015 m. vasario 5 d. įsakymas Nr. V-82, TAR, 2015-02-05, Nr. 1775

Park, D., \& Reuter-Lorenz, P. (2009). ‘The adaptive brain: Aging and neurocognitive scaffolding', Annual Review of Psychology, 60, 173-196.

Phelan, E. A., Anderson, L. A., Lacroix, A. Z., \& Larson, E. B. (2004). Older adults' views of "successful aging"- How do they compare with researchers' definitions? Journal of American Geriatrics Society, 52(2), 211-216. Available at http://www.medscape.com/viewarticle/467925 (Retrieved on 02/02/2015).

Rowe, J. W., \& Kahn, R.L. (1997). Successful aging. Gerontologist, 37, 433-440.

Strawbridge, W.J., Wallhagen, M. I. \& Cohen, R. D. (2002). Successful Aging and Well-Being: Self-Rated Compared with Rowe and Kahn. The Gerontologist, 42 (6), 727-733. Available at http://gerontologist.oxfordjournals.org/content/42/6/727.full.pdf (Retrieved on 03/02/2015).

Taikomasis suaugusiujų švietimo tyrimas (2011). Vilnius: Socialinès informacijos ir mokymų agentūra.

Tam, M. (2013). Perceptions of successful ageing and implications for late-life learning. Studies in Continuing Education, 35(3), 281-298.

Trečiojo amžiaus universitetų sistemos veiklos analizè (2012). Vilnius: Socialinès informacijos ir mokymų agentūra. Valstybine švietimo 2013-2022 metų strategija (2013). Lietuvos Respublikos Seimo 2013 m. gruodžio 23 d. nutarimas Nr. XII-745. Valstybės žinios, 2013-12-30, Nr. 140-7095. 